http://jmscr.igmpublication.org/home/ ISSN (e)-2347-176x ISSN (p) 2455-0450 crossref DOI: https://dx.doi.org/10.18535/jmscr/v9i10.08

\author{
(1) Journal Of Medical Science And Clinical Research \\ IGM Publication \\ An official Publication of IGM Publication
}

\title{
Euthanasia in Thailand and should it be legal
}

Authors

Kimhun S., Witsarut M.

\section{Introduction}

In today's society, most people, even authorities, are aware of freedom, which implies that everyone may do anything they want as long as they don't offend others. Most regions have transformed their regime to democracy throughout the last century in order to serve their constituents equally. People have been considering their rights, from rights to live to rights to die. There are only eight countries in the world that Euthanasia is legitimate; the Netherlands, Belgium, Luxemburg, Spain, Canada, Switzerland, Australia, Colombia, Germany, and Japan. And only six states in the USA; Washington, Montana, New Mexico, Oregon, Vermont and California. Although technological advances can remedy people's illness, they still suffer from excruciatingly painful torture from an incurable disease; consequently, Euthanasia is probably the only way to peacefully pass them away.

\section{Solution}

Euthanasia derived from a Greek word that means "good death" is a way of bringing people to a state of unconsciousness or vegetative state, followed by death, without causing them pain. For decades, it has elicited strong feelings about medical ethics and legislation. Certain religious countries, such as the Roman Catholic Church, the Orthodox Church, and Islam, clearly condemn this strategy.
Despite the fact that some pass legislation to properly support this. There are certain details about euthanasia to distinguish in the following ways:

By deliberation

Casualties suffer from severe physical and mental disease, prompting them to consent to others allowing them to die naturally, a process known as Voluntary Euthanasia.

In certain circumstances, casualties are in a situation where they are unable to demonstrate their purpose, such as if they have a legal representative, guardian, or successor. In the legal process, A court may permit that legal representative to do so instead, a practice known as involuntary euthanasia, under the legal process. (Varathip Thongdech, 2020)

The right to have a good death is the right to pass away naturally and peacefully without having to go through painful and expensive life-prolonging medical interventions. It is the right to die with dignity. Refusing life-sustaining medical technology during one's terminal ailment is currently the right of every Thai under the law. Yet most people still ignore this, nor do they know about palliative care services which help terminal patients die naturally and comfortably instead of being kept alive artificially. According to research on Public Awareness and Attitudes toward Palliative Care in Thailand by Thailand 
Development Research Institute (TDRI), more than three fourth of Thai people do not know that palliative care is valid for terminal patients. Moreover, $79 \%$ have not heard of a living will, a written directive prepared in advance to refuse life-prolonging medical technology (Wannapha Kunakornvong, 2019)

The active and passive types of euthanasia are usually distinguished. These terms are considered misleading and unhelpful by a number of authors. They are, nonetheless, used in the literature and discussion and should be understood as a result. Active euthanasia is possible if deliberate techniques for ending patients' lives are used, such as the delivery of potassium-containing drugs to induce cardiac arrest, which is outlawed in the United Kingdom. The withholding of lifesustaining treatment is known as passive euthanasia. It is a moral question whether the prescription of progressively essential, although toxic dosages of opioid analgesia is considered active or passive euthanasia. (Capt NM Harris, 2013)

In Thailand, the majority of Thais refuse to prepare themselves for euthanasia or a good death because there is still a huge taboo to talk about death in the Thai community, bringing it up with a bad omen or a curse. Even when one is not scared of death oneself, advising preparations for the imminent death to a family who has chronic ailment is blasphemy and rude. The obstinate use of expensive medical care is symbolised as love and gratefulness. But it sometimes ends up with bankruptcy. According to Section 12 of the National Health Act 2007, "a person has the right to write a directive letter to reject medical interventions which can only prolong one's terminal stage of life, or to refuse medical services to discontinue torture from illness". People can have the right to natural death (passive euthanasia), not an active one. There are discrepancies between natural death and active euthanasia (National Health Commission Office, 2018)

According to Prof. Dr. Chanchai Sithiphan, a dean of Chulalongkorn University's Faculty of Medicine, the future of euthanasia in Thailand is determined by a doctor's perspective. He has spoken with doctors in countries where euthanasia is legal. Firstly, whether or not the doctor accepts euthanasia as a means of allowing people to die peacefully. Individual initiatives that euthanasia is acceptable and beneficial might be the source of this. Is this a violation of medical ethics? We have 4 Codes of Ethics; patients' benefit, no drawback to patients, the need of patients, and social justice. If a physician considers bringing death to patients as a disadvantage, one will decide not to do so. Some, however, regard keeping alive artificially and painfully as helping them soothe, not against one's belief to benefit patients. This team of doctors believes euthanasia is both appropriate and feasible.

\section{Conclusion}

We all know that passive euthanasia is partly available. For example, if we just stop functioning the ventilator of a vegetative-state patient, he or she will pass away instantaneously. On the other hand, for those who suffer from movement disorders and neurologic disorders affecting the brain or spinal cord, causing difficulty in locomotion. Thus, they might have thought of being a burden for their offspring and relatives to supervise them. Some probably undergo the impoverishment somewhat might cause their family to go bankrupt. The issue of euthanasia in Thailand nowadays is not urgent, in the future, however, when Thais face aging-population society, euthanasia would be reconsidered and argued to suit the future community.

\section{Reference}

1. Bailey FA, Harman SM. Palliative care: the last hour and days of life. Up To Date (2015). [Internet]. Available from http://www.uptodate.com/contents/palliati ve-care-the-last-hour-and-days-of-life.

2. Wannapha Kunakornvong, TDRI Insight. Greying nation must talk about death. 
[Internet].

Available

from

https://tdri.or.th/en/2019/04/greying-

nation-must-talk-about-death/

3. Capt NM Harris, MB ChB MRCS(Eng)

RAMC: The Euthanasia Debate. BMJ

Military Health (2018). [Intenet].

Available from

https://militaryhealth.bmj.com/content/147

/3/367

4. Warathip Thongdetch: Anaesthesia and

Euthanasia: Congruence but Difference.

Faculty of Medicine Siriraj Hospital,

Mahidol University (2020). [Internet].

Available from https://he02.tci-

thaijo.org/index.php/anesthai/article/downl oad/246785/167770/

5. World Health Organization. Palliative Care 2015. [Internet]. [Retrieved Jun 26, 2019]. Available from http://www.who.int/mediacentre/factsheets /fs402/en/(Footnotes) 